\title{
Bermuda Triangle: Mystery Solved
}

\section{Paul T E Cusack*}

23 Park Ave. Saint John, NB E2J 1R2, Canada

*Corresponding author: Paul T E Cusack, 23 Park Ave. Saint John, NB E2J 1R2, Canada.
Received Date: September 05, 2018

Published Date: October 04, 2018

\section{Introduction}

The Bermuda Triangle is a mystery no longer. It is simply methane gas bubbling up from the once swamp (swamp gas) below the waters of that area. The void left behind swallows up airplanes and ships which are never found. Fresh water is found which comes from the reaction of methane $\mathrm{CH}_{4}$ with salt water $\mathrm{NaCl}$.

$$
\mathrm{CH}_{4}+4 \mathrm{NaCl}+2 \mathrm{H}_{2} \mathrm{O}==>\mathrm{CCl}_{4}+4 \mathrm{NaOH}+\mathrm{O}_{2}
$$

The carbon in the methane takes up the chloride in the salt leaving fresh water behind.

$$
\begin{aligned}
& \mathrm{CH}_{4}+\mathrm{Na}(\mathrm{OH})+4 \mathrm{HCl}==>\mathrm{CCl}_{4}+4 \mathrm{NaOH}==>4 \mathrm{NaCl}+4 \mathrm{OH} \\
& 2 \mathrm{CCl}_{4}+8 \mathrm{NaOH}==>8 \mathrm{HCl}+2 \mathrm{CO}_{2}+8 \mathrm{NaCl}+2 \mathrm{O}_{2}
\end{aligned}
$$

$$
\begin{aligned}
& 8 \mathrm{HCl}+8 \mathrm{NaCl}+2 \mathrm{CO}_{2}+2 \mathrm{O}_{2}==>2 \mathrm{CCl} 4+8 \mathrm{NaCl}+4 \mathrm{O}_{2}+8 \mathrm{H} \\
& 4 \mathrm{O}_{2}+24 \mathrm{H}_{2}==>4 \mathrm{H}_{2} \mathrm{O}+2 \mathrm{O}_{2} \text { (Fresh Water) }
\end{aligned}
$$

There are 4 parts water for every one-part methane. So, for 1 mole of methane, there is produced 4 moles of fresh water.

\section{Conclusion}

Methane is less dense than air. Both ships and planes are dependent on fluid pressure to stay afloat. Drop the pressure under the wing of an airfoil, the plane drops out of the air. drop the water pressure that floats a boat and the boat sink. No remains are found because the methane gas leaves behind a large void. Mystery solved! 